\title{
Understanding Learner Interaction in Web Based Learning to Improve English Speaking Skills in Second Grade of SMAN 4 Senior High School Bandar Lampung: Using Canvas Learning Management System
}

\author{
Upeka Mendis $^{1}$, Yanuarius Yanu Dharmawan ${ }^{2}$ \\ ${ }^{1}$ English Education Study Program Teacher Training and Education Faculty, Universitas Bandar Lampung, \\ ${ }^{2}$ English Education Study Program Teacher Training and Education Faculty, Universitas Bandar Lampung
}

\section{ARTICLE INFO}

\section{Keywords:}

Web Based Learning, English Speaking Skill, Canvas Learning Management System

\begin{abstract}
Understanding learner interaction in web based learning to improve English speaking skills in second grade classroom of SMAN 4 senior high school Bandar Lampung: using canvas learning management system, English Study Program, Teacher Training Faculty of Bandar Lampung University.The objective of conducting this research is to find out the interaction in Canvas Learning management system (LMS) in the speaking classroom and effects of using Canvas LMS to improve speaking skills. After it is confirmed that there is indeed necessity behind the action, I will explain concepts of interaction, Canvas LMS and speaking skills. The participants of this research are students in second grade of SMAN 4 senior high school. They are selected as data resource to know about interaction and effects of using Canvas LMS. From them, I retrieve data to be analyzed. By giving questionnaire, observing and conducting independent sample t-test method gives me some findings to discuss. The results show that there is indeed necessity in doing English speaking lessons in Canvas LMS. Moreover it is about students' interaction and effects to improve English speaking skills. First is about interaction, it is the main ingredient in any kinds of learning methods. There are three main types introduced my Moore (1989), there are learner-instructor, learner- learner and learner-content. Those types necessary appear in web based learning. These interactions lead to improve students' speaking skills too.
\end{abstract}

This is an open access article distributed under the terms of the Creative Commons Attribution 4.0 International License, which permits unrestricted use, distribution, and reproduction in any medium, provided the original work is properly cited. (c) 2019 Upeka Mendis, Yanuarius Yanu Dharmawan.

\section{INTRODUCTION}

${ }^{1}$ Corresponding author's address: English Education Study Program Teacher Training and Education Faculty, Universitas Bandar Lampung, Bandar Lampung, Indonesia

e-mail: upekaubl2011@gmail.com

${ }^{2}$ Corresponding author's address: English Education Study Program Teacher Training and Education Faculty, Universitas Bandar Lampung, Bandar Lampung, Indonesia

e-mail: yanu@ubl.ac.id 
Nowadays technology takes very important place because people use various kinds of gadgets as tools to help them for everything that happen in their life. Mondal (2016) states there are perhaps no field of human life which has not been affected by technology. Agriculture, industry, profession, health, education, art, political processes, recreation, religious activities and daily life activities all are under the influence of technology. Based on her statement, technology is main need for human, because it helps to influence many fields such as business, health, art, education and so on. In this wide filed I focus on Education. Omer et.al (2015) clarified that Education empowers people critical skills and means to create opportunities for sustainable and viable personal and economic growth. According to their statement education is very important, because it can make people to think critically and give many opportunities in working fields. That is one of the reasons for some researchers combine technology with education and invents web based learning method to make learners equal with the globalization (Sidabalok and Sela, 2018). Web based learning has become an integral tool to deliver education due to development of technology.

Using web based learning in the classroom is very common strategy today because it is very fixable, comfortable, and self placed learning, and lower cost method that can use for the learning. Based on these reasons most learners prefer to have web based leaning instead traditional classroom method. Norman (2016) reports there are several problems with the traditional system of education. First of all, we need to pay thousands of dollars per term to attend a prestigious school. Other thing is about the all those budget cuts, busy classrooms, and course shortages, we will not always get the chance to study exactly what we want. Based on her clarification traditional classroom method is so costly and less management, so she suggests that web based learning is best method for the effective learning. Omer et.al (2015) said that E-learning uses numerous types of electronic media, educational technology, and information and communication technology to deliver education. E-learning provides unprecedented opportunities for people to learn in a more personalized, flexible, and portable manner without the restriction of time and space. In this theoretical review they described E- learning is very comfortable and time saving learning method. It gives many wide opportunities for the learners to learn many things.

Many studies demonstrated that success or failure of web-based learning depends on interaction. Woo \& Reeves (2008) state that Interaction is an essential ingredient of any learning environment such as in face-to-face classroom-based, synchronous/asynchronous online education, or blended models. They pointed out that interaction is very important element in any kind of learning style. Interaction is the necessary element for the any kind of learning style because by observing interaction in the specific learning method can conclude whether it is effective learning style or not. Wheeler (2012) adduces that interaction. For many teachers, it has become the keystone of contemporary education. Many studies into the importance of interaction in education have been conducted. We all have different definitions of what interaction involves, but most of us agree - it's an important component of learning". Interaction is a very important ingredient in any kinds of learning.

Canvas group (2016) sate Canvas is a modern, adaptable and reliable learning. This system is easy to use because it is available for mobile and also time-saving. Other thing is, it gets used because it's designed to get out of students way, and students get what they want from the lesson. This system can develop student's social interaction and also they can have discussions, take quiz, and do assignments. Moreover It is a modern learning to manage system that helps educators to learn.

In this research I compare web based learning with the traditional classroom method. In traditional classroom teacher where teach the lesson and the students are those who have to listen. Students feel bored in the lesson in this condition. It is because they do not get any chance to express their idea about the lesson, they will keep silent even though they want to discuss with their teacher and with their friends. There may be only 3 or 4 students that can answer the teacher's questions. Learners cannot get good effects from the traditional class method nowadays 
due to this condition, so most teachers try to use online class. Online class is better to be use rather than traditional class method nowadays.

In online class students can express their idea about the lesson and also teacher can motivate learners to speak up. Every student will get the opportunity to speak up. Students can use their critical thinking and understand the lesson very well than traditional class method. In online class method teacher discuss the lesson with learners. Teacher tries to know learners' opinion about the lesson. From that learners can improve their intellectual ability in learning. When teacher asks to do group assignments, learners can develop their confidence to work in a group.

\section{Blended learning}

Blended learning is a very common learning method because of the development of technology. Nowadays many students use smart phones, computer, or any other gadgets to do many things such as social networking, gaming, taking photos, watch online video and so on. For this reason many teachers use technology in the classroom. Blended learning is education method which is combining internet and digital media with traditional classroom method. In addition it is very easy and flexible method. In order to describe about this, there are some theoretical explanations from Guzera and Caner (2014), Fundamentals of blended learning (2013:5), and Fleck (2013).

Guzera and Caner (2014) define blended learning is a most popular learning strategy since 2000. Students can learn better at blended learning compared to the traditional classroom environment. It is useful, enjoyable, supportive, fixable, and motivator for them. In blended learning students do more works than teacher in the classroom. Students learn same lesson in online as they do in the classroom from that they can improve their critical knowledge about the lesson moreover they develop their social interaction through more collaboration.

Fundamentals of Blended learning (2013:5) points out that blended learning can increase access and flexibility for learners. It can increase level of active learning, and achieve better student experiences and outcomes. It is very flexible method that can be used for the learning as students will be very interest with it. Moreover blended learning is very adjustable method and there are some benefits to the learners and to the teachers. Students can develop their learning skills, become active learner in the classroom and explore their ideas about the lesson. By using this modern method teachers can improve their teaching skills and can give more time to learners to practice.

Fleck (2013) elucidates the term blended learning as a mix of conventional face-to-face elements combined with on-line elements. In blended learning students do not only use technologies to learn, but also they use social interactions between teacher and students in the classroom combine with face to face method for instance when students have got problem in understanding lesson, they can discuss and get many information from the teacher or other learners the use of emails, discussion boards and chat rooms. In addition blended learning develops students' social interactions and critical knowledge.

\section{Interaction}

Interaction is a main key to know whether the teaching or learning is effective or not. Without meaningful interaction we cannot measure how well or not learning activity is. It is most important element in teaching and learning process. There are three theories that I will present in this concept of interaction. There are some theoretical statements from Woo and Reeves (2007), McNary and Song (2011), and Adnan and Hassan (2015). These theoretical explanations are useful to understand the concept of interaction.

Woo and Reeves (2007) explain considerable definition about interaction. They describe that instructional technology is a design which people try to increase effectiveness of learning through the integration of pedagogy and technology, so instructional designers are the promoters in this field. Therefore they try to promote interaction in specific learning field because it is one of the key 
components of good pedagogy and an essential ingredient of any learning environment such as face-to-face classroom-based, synchronous/asynchronous online education, or blended models. When teachers introduce new learning filed, they try to promote interaction to students in order to get positive effect from the learning method. By looking at this theory I can tell interaction is essential element for any kind of learning strategy.

Mc Nary and Song (2011) describe one area that has been identified as an important factor affecting students' learning experiences in online learning environments is student interaction. Interaction in learning settings is a necessary and fundamental process for knowledge acquisition and cognitive development and it has long been a focus of research for instructional designers. Online technologies such as asynchronous discussion forums provide the opportunity for learners to engage in social interaction by reading and responding to peers' and instructors' postings. Therefore in online learning student interaction takes main place. Adnan and Hassan (2015) define sentence as;

"Social interaction plays a fundamental role in the learning process. Interaction is an effective way of developing skills and strategies. In an online setting, effective teaching depends on a thorough understanding of the nature of interaction and how to facilitate interaction through technologically transmitted communications".

In every learning process social interaction takes very important part. It is effective way to develop specific skills and strategies in any learning method. Therefore in online learning effectiveness depends on understanding of interaction and the way it facilitate through technology. It is the most important thing in web based or online learning. These three theories above argued that interaction is the major element or ingredient in any kind of learning, because interaction is the measuring tool of the learning process whether effective or not. In learning process quality depends on the interaction, so in order to have effective web based learning method, it must has meaningful interaction.

\section{Types of Interaction}

Interaction is very important element in online learning. When I want to discuss about interaction, there are three types of interaction; such as learner- instructor, learner- learner, learner- content interaction. Those types offered by Moore (1989). Learner- instructor interaction is instructor helps learners to feel a greater sense of community and leads them to get great level in the classroom lessons. Learner- learner interaction is learner interact with their peer therefore it helps students to develop problem- solving and critical thinking skills and also supports to have productive and satisfying learning. Learner- content interaction is interactions that occur between learner and content of the lesson or activity.

\section{Speaking}

There are four basic skills in learning English language, if learners can improve those four skills learners consider as successful English learners. Among those four skills, speaking takes very important place, because most of language learners' first target is to improve their speaking skill in specific language. Looking at the reasons why we should learn new language, first reason is to communicate with people around the world therefore we must improve our speaking ability. In concept of speaking I introduce some theoretical explanations from Al-Tamimi \& Attamimi (2014), Somdee and suppasetseree (2012), M. Hamad (2013) and Fahad (2013: 84). These theoretical statements explain about the importance of the speaking skill.

Al-Tamimi and Attamimi (2014) argue speaking is the ability to express something in a spoken language. It is simply concerning putting ideas into words to make other people grasp the message that is conveyed. Speaking is some talent to express the ideas into spoken form and tell to receiver by using specific language. Therefore speaking is skill which has to practice with others.

Somdee and suppasetseree (2012) explain speaking is considered to be the most important in a second language. It is the ability that requires the process of communicative competence, 
pronunciation, grammar, and vocabulary improving. Speaking is very important skill because by doing speaking learners can improve their pronunciation, vocabulary, grammar and also they can be confident to sue that specific language. Egan (1999) states' speaking is at the heart of second language learning. It is arguably the most important skill for business and government personnel working in the field, yet it appears particularly vulnerable to attrition. When we study second language because most of time we speak with other people, we must understand what others are saying. This skill is most important in business filed and political filed because without speaking how can we express our ideas and opinions about the situations.

M. Hamad (2013) says that speaking skills are regarded a very important and unique skill. It is the first output of any language and the only skill which you need partner to practice, you can listen to audio resource alone, you can read a book alone, you can write a letter alone, but you cannot speak alone, you need someone to speak to. Learning speaking ESL/EFL skills highly depends on classroom lessons and language - labs. Moreover speaking is skill that we cannot do alone because we need some partner to speak and also speaking skill learner has to practice. If learner can practice more about speaking that learner is consider as a fluent.

Fahad (2013:84) reveals in his study that most of Saudi students find it inappropriate to speak in class because of their fear to be seen as verbally challenging their teachers' views openly and publicly. Speaking skill seems to be very easy, but actually it is the most difficult to the learners. According to Fadad learners' get challenging part when they want to speak, such as they feel shy, nervous and fear. Learners feel shy when they want to speak in front of the class, whether they will do some mistakes or not. This is the reason most learners failed in this skill, even though they are good in reading and writing but in speaking they will be backward. That is why learners have to improve their speaking ability by practicing together with the partner and forget the fear to speak.

From all those experts' ideas we can conclude that speaking is most important skill when learning second language. Without speaking how learners can improve their knowledge, how can they think critically, how they can express their ideas, so by speaking skill helps to learners build up their knowledge about specific language. Speaking skill is practical skill than other three skills, because without practicing learner cannot get fluency, and also learner cannot practice speaking alone, so speaking skills influence learners' social interaction.

\section{Canvas Learning Management System}

Canvas learning management system is a popular online learning system for learners in school until to higher education. Canvas LMS developer is Instructure which is an educational technology company based in Salt Lake City, Utah. This is a new system that can use for the effective learning, so in the concept of Canvas I am going to give more explanation about the Canvas and benefits of this system. In order to explain that I use theoretical explanations from Littlefield (2016), Reeve (2015), Reviews.financesonline.com (2016) from these theories, experts pointed out about the Canvas and benefits of this system.

Littlefield (2016) describes Canvas is one of the best online learning platforms available and also it offers some unique Web 2.0 features. This system makes easy for students and instructors to manage the learning process. It is very simple and flexible system, so it simply feels better to use than most other online learning platforms.

Reeves (2015) defines sentence as;

"Canvas is still the most flexible and easiest to use LMS on the market. The high school and middle school where my children attend are now using Canvas. My kids like it because they can work on things at home and access materials they need to complete assignments. Canvas works well at our institution, and provides great functionality to support a wide range of courses". 
Reeves is a high school teacher and he has four year experiences in using Canvas LMS, so he has found this system is very simple and easy to interact with the students. In this system students can study outside the classroom and also they can complete assignments. Other possibility is students can create their own group for doing course projects.

Reviews.financesonline.com (2016) says Canvas LMS is a popular online learning system. It is a system that offers possibilities for the learner to educate or learn the way they want to. In this system instructor and students interaction is highlighted. Moreover in this system learner and develop their social interaction by doing peer work.

By looking at those theories Canvas LMS is very simple and useful learning system. It is useful for the students to develop their learning knowledge and also increase their social interaction among other learners. Students can do their course projects as a group and they can discuss about the lesson. Teacher and students interaction also takes very important place in this system because teacher can give grades directly to students, give comments and so on.

This research is not the first investigation. There are many researchers that did the similar observation though with different object of investigation. This part is showing the researches that were done by other researchers as the supporting reference for this research. The first related study is the research was conducted by Younhee and Thomas C. Reeves, entitled "Interaction in asynchronous web based learning environments". Secondly, the research was investigated by Bude Su,Curtis J. Bonk, Richard J. Magjuka, Xiaojing Liu, and Seung-hee Lee. ,entittled "The Importance of Interaction in Web- Based Education".

Interaction in asynchronous web based learning environment research conducted by Younhee Woo from Korean National Open University and Thomas C. Reeves from The University of Georgia. It was qualitative research. It focused on explaining the factors to explore the importance and characteristics of meaningful interaction in online learning. It involved one hundred and twenty two participants and they were undergraduate students from UK. In this research researchers wanted to know that how learners get used with the web based learning, since it was new for learners. Other most important thing is they want see learners interaction in web based learning. They used some strategies to promote interactions. Researchers want to know whether web based learning is good method to learn or not. In their research they concluded that web based is very useful method for learning. Web based learning can give new learning style for the learners and so on. In this research they promote interaction among students, so I also use those same strategies for my research to promote interaction among students.

The Importance of Interaction in Web- Based Education was conducted by Mr. Bude Su, Mr.Curtis J. Bonk, Mr.Richard J. Magjuka, Mr.Xiaojing Liu, and Mr.Seung-hee Lee. They are from Indiana University. It was qualitative research. It involved twenty six faculty members and 10 second-year online MBA students as participants. It was focused on the importance of interaction. Researchers explained importance about each interaction. And also they point out that some web based learning use same learning method as traditional classroom. So in here they tried to explore idea about importance of interaction. They want to know about quality of online program. They explained about explosive growth of online program and about pedagogical experiences that can help establish a high quality online program. In this research researchers has found that why most of instructors do not promote interactions and they point out some reasons in their research. About the promoting strategies are same as what I am going to do in my research. Those are same instruments, but in my research I only forces to meaningful interaction not about importance of interactions.

Thirdly, the research was investigated by Sidabalok and Dharmawan entitled "The Role of Blanded Learning in Activating Students' Speaking Ability". This research told about using schoology can be used on laptop, or smartphone as a media in doing blended learning method 
that is a combination of face-to-face meeting between teachers and students. it was qualitative and quantitative research.

This researcher did the same thing in observation that was observing on online meeting and faceto-face meetings. In online meeting I did not interact with my students online, the students used the media to improve their speaking ability after the class ended, but in this research, the researcher did online meeting too to make sure the students' speaking improvement.

I have the differences and similarities with three researches above. I also investigate about students' interaction in web based learning. I use descriptive qualitative. To collect the data, I use questionnaire and interview. After that, I analyze the data by using qualitative analysis. The procedures in my research are doing observation to find the problems, determining the problem formulation, setting the literature review, collecting the data, analyzing the data, and making the conclusion.

\section{METHODOLOGY}

The research used mix method research. Creswell (2012) describes A mixed methods research design is a procedure for collecting, analyzing, and "mixing" both quantitative and qualitative methods in a single study or a series of studies to understand a research problem. Therefore this research used both qualitative and quantitative methods, so by combination we can understand the research problem and question than either by itself.

I wanted to recover about how participants interact in web based learning. I need to have deeper understanding about students' interaction in web based learning process which is not observable by scores. It is conducted using questionnaire, observation to collect data. I gave the questionnaire that include 15 questions to the participants and then analyze the answers given by them. Those fifteen questions created based on the interactions, flexibility and usability. Participant's interaction is what to be observed here.

Moreover I wanted to cognize effects of using Canvas LMS in speaking classroom. Therefore I wanted to observe students' scores. It is conducted independent sample t-test method in analyzing the data. I used SPSS program to analyze the independent sample t-test. I divided into two groups such as control and experimental groups. Then I gave pre test before treatment and post test after the treatment. I scored students speaking ability based on four criteria; there are fluency and coherence, lexical recourse, grammatical range and pronunciation.

Creswell (2012) says that a variable is the characteristic or attribute of an individual, group or educational system, or the environment that is the interest of the research study. In this research, there were two kinds of variables, they were independent variable and depended variable. Creswell (2012) states that an independent variable that was measured in a study. Therefore in this research an independent variable was by using canvas LMS effects students speaking skills. Next one was about dependent variable is outcome, so in this research dependent variable is students improvement in speaking by using Canvas LMS. Then another variable was, investigate or observed the meaningful interaction in web based learning. It was developing students speaking skill by using Canvas system. By using those techniques can develop interaction in web based learning. It was the basic unit of the information studied or interpreted in this research.

Beside of observing interaction, I wanted to see how learners improve the speaking skill by using Canvas learning management system, because in Canvas guides learners to do more conversations than traditional classroom. They discussed many things with the peer, and consult the instructor to solve some problem they might have in the lesson. Speaking skill is very practical, so learner improvement of speaking depends on the practice. In this research I observed interaction in web based learning and how can web based learning help learners to improve their speaking skills. 
This research was conducted in Sman 4 Bandar Lampung Senior high school. This school located in Jalan Dr.Ciptomangunkusomo No.88 Teluk betung Utara Bandar Lampung. In conducting my research, I selected the participants as my subjects of the research. There are students of second grade.

In collecting the data, the participants observed, and gave questionnaire. The participants observed for about one month. Participants did their lessons in online and after the class they practiced more in the offline classes. How students' interaction in web based and in which types that most of students interact in web based. Questionnaire was given for the students to know what they think about the web based, will web based influence students to speak up or not , whether they use their critical thinking to explore the ideas or not.

Questionnaire used to know learner opinion about the web based learning. I gave 15 open- ended questions and used Google forms to collect the answers. In there I asked some questions to see whether they used their critical think or not, was this system help them to achieve goals of lesson, did they waste time to understand the lesson, their idea about peer working, and what kind of classroom method do learners prefer and so on.

In observation I could see whether learner truly interact with LMS or just uses it same as traditional method, how learner deal with the psychological behavior, such as when they speak in front of the their performance, and main thing is how learner preparation about the lesson, because in LMS instructor introduce lesson in discussion form, next day learners had to come up with more information about the lesson. From these methods I concluded web based learning produce meaningful interaction.

Instrument was the tool to collect the data or it can be defined as the way how to collect the data. The instruments that I used are observations, questionnaire, pre test and post test. Observations were used to see learner interaction in Canvas LMS. A questionnaire was used to get the data based on how students could answer with the objective answer naturally. Pre test and post test use to get the information about effectiveness of using Canvas LMS and how the students could improve their speaking ability. In order to count the scores I used SPSS program to analyze the independent sample t-test. From that I could see whether learning speaking in online class effective or not.

This research was going to use questionnaires, observations, pre test and post test to collect data before and after the research. By using questionnaire researcher supposed to know students' opinion about web based learning, whether web based learning process improve their intellectual ability or not. By doing observation, I wanted observe student's performance in web based class. Web based effected to students to understand the lessons. There were two observations; observation in online class and offline class.

Observation in online class, I observed how students get used with the online class, how student's participation in online class, how can they explore their opinions about the lesson and how can they use their critical thinking to understand the lesson in online class. Observation in offline class the I observed about how learner experience about the online class, how they worked as a group, relationship between learner and teacher, and how was learner performance in offline class. In independent sample t-test I wanted to investigate students' improvement in speaking skills.

\section{DISCUSSION}

There are three main types of interaction that can appear in web based learning method. There are learner- teacher, learner- learner and learner content. Firstly I gave two questions to know about learner- teacher interaction. Based on results, there are 58.8\% students agreed and $41.2 \%$ students strongly agreed that teacher's feedback was helpful to understand the lesson and also $52.9 \%$ students agreed and 47.15 strongly agreed that they discussed more about the lesson with teacher. 
Therefore almost $100 \%$ students agreed that teacher collaboration was very helpful to understand the lesson and also it was help them to speak without any hesitation.

Based on the results $47.1 \%$ students agreed and $35.3 \%$ strongly agreed that peer collaboration was helpful for the learning process in Canvas LMS, but 17.6\% students disagreed that they did not work with the peer. Then $58.8 \%$ students agreed and $35.3 \%$ strongly agreed that they have been discussed about the lesson. On the other hand 5.9\% students disagreed with this statement. Therefore I can say that most of students were collaborate with their friends to understand the lesson, but some students prefer to ask some questions from teacher than their friends because sometimes their friends also could not understand the lesson and cannot help their friends for understanding the lesson.

Moreover it leads to know whether the materials were helpful to students to understand the lesson and did those materials lead them to speak up. Therefore $52.9 \%$ students agreed and $35.3 \%$ students strongly agreed that materials were helpful, yet $11.8 \%$ students disagreed with the statement. The reason is, students were still in young age and mostly they do not like read and see the materials. Even they read mostly they could not understand what were materials taking about. That is why they tend to ask from teacher or their friends instead understand the lesson by their own selves.

Based on observation results, students had some problem to log in to Canvas LMS by using mobile application, however they had to use browser to take online class. For the first day there were only thirteen students attended to the online classroom. Before students were quite confused to use for the first time, but they were active when they had discussed about the lesson. In addition they gave many opinions about the lesson, discussed with their friends and so on. Some students did not attend to the class due to log in problem. For the second and third day students were excited about the lesson, they asked many questions form teacher. Moreover they tried to collaborate with teacher and their friends.

From all of the responses I can say that the most interaction that appeared in Canvas LMS was learner- instructor interaction. As we know in traditional classrooms students do not have courage to ask questions from the teacher and also do not have closer relationship like in online classroom. Students felt much more confident to talk and have much closer relationship with teacher in online classroom. Beside this other two interactions also helpful to understand the lesson, such as they had to discuss the lesson with their friends, do group work and get ideas to speak from materials (videos).

Pretest of control group has done in the first meeting. In this test, the students had to introduce their self and tell about their future ambition. I tested their speaking by using these criteria such as fluency, coherency and contrast, performance, pronunciation and grammar. Each criterion got 10 points. Therefore, if the students can speak based on those criteria correctly they will get perfect (100) score.

In the pretest, the score of control group is in intermediate level. Based on table 4.2, it consists of 40 as the lowest score and 57 as the highest one. It means that in pretest, students are only able to speak without coherence, limited explanation and ungrammatical way. The total score of control group in pretest is 827 . It consists of approximately nine students who got $<50$ score and eight students got $>50$ score. After pretest, treatments gave in three meetings. The treatments are given by using traditional teaching. I asked them to watch video and asked them to explain about the video. Posttest is the last activity which is done in control group. The procedure of posttest in control group is told about special person in their life. Based on table 4.2, the lowest score is 45 and the highest score is 72. It also shows that the students' score in posttest is higher than in pretest. There is approximately only one student who got $<50$ score and 16 students got $>50$ score. It means that the students who get $\leq 50$ score are decreased. 
Experimental group was taking English lessons by using Canvas LMS. There were 17 students included. Therefore, pretest and posttest are administered in order to know the students' speaking ability before and after treatments. The first activity which is done in experimental group is pretest. The procedure of pretest in experimental group is the same as in control group. In pretest, the students' score of experimental group is also low. Based on table 4.2, the lowest score is 45 and the highest is 67. It means that in pretest, students in experimental group were only able to speak without any grammatical order, miss pronounce words and their content and vocabulary was limited. The total score of experimental group in pretest is 932. It consists of approximately four students who get $\leq 50$ score and thirteen students who got $>50$ score.

After pretest, treatments are given in four meetings by using Canvas. On each meeting, I used many videos and materials. After the lesson they had to submit their assignment by recording because I wanted to improve their speaking skills. Posttest is the last activity which is done in experimental group. The procedure of posttest in experimental group is the same as the procedures of pretest. Based on table 4.5, the lowest score is 58 and the highest score is 82 . It also shows that the students' score in posttest is higher than in pretest. $100 \%$ or 17 students of experimental group get $>50$ score. It means that their score in posttest are significantly increased.

The students' scores of both control and experimental group are quite low in pretest. Actually the students felt nervous and made many mistakes when they speak in front of the class. However, they do not like to speak because mostly they do not have any ideas to speak. Most of students felt less motivated because they did not understand the lesson. In posttest, the scores of both groups are increased. The total score of control group in posttest is 1002. The total score of experimental group in posttest is 1136. It increases 204 points from the pretest score.

Based on the result above, we can see that experimental group scores increase significantly higher than control group. So, we can conclude that students who are given treatments by using Canvas LMS have higher score than those who are given treatments by traditional teaching.

After I was getting the pretest and posttest data, SPSS program was used to calculate the mean scores of both experimental and control group, as well as to examine the hypothesis. SPSS is used in order to reduce the errors in calculation as well as to make the t-test analysis simpler and more efficient. In using this kind of software I only need to put the pretest and posttest score of experimental and control group into the software, it will be calculated by the software. The data were analyzed by using independent sample t-test analysis.

\section{CONCLUSION}

Based on the result of the research, I conclude that there was meaningful interaction and by using LMS is effective for speaking classroom. I wanted to know about students' interaction in Canvas LMS. Moreover I wanted to know which type of interaction that will appear in the LMS. Based on the result I can conclude that most interaction which was appeared in the lessons is learnerinstructor. In detail $100 \%$ students agreed that teacher collaboration was helpful them to understand the lessons and it motivated them to speak up. Moreover about the learner- learner interaction $82.4 \%$ students agreed that peer work was helped them to speak up and think more critically, but only $17.6 \%$ were against with the statement. However that interaction was almost helped students to sympathize the lesson. Then learner- content interaction. 88.4\% students agreed that materials supported them to understand the lesson and think more critically. In addition I can conclude that three types of interactions occurred in Canvas LMS.

By looking at the T test result I can see that lessons in Canvas LMS were effective. By looking at experimental group scores we can see that. Therefore experimental group total score was 932 and also t- count 2.636 is higher than t- table 2.042. Since the sig. 2-tailed value is lower than sig. level $(0.013<0.05)$, it means that the means of experimental and control group are significantly different. Therefore, the alternative hypothesis $(\mathrm{Ha})$ is accepted and null hypothesis (Ho) is rejected. However control group scores in pretest were 827 and posttest were 1002, so I can say 
that there were also some improvements in control group even though that class was lead by traditional method.

Based on the results I can see that there is some improvement in students' speaking skills by using Canvas LMS in the classroom. Normally in traditional classroom student just follow the teacher based system, but in LMS mostly one who speaks is students and there is good relationship between teacher and students. Moreover students get easy to collaborate with peers. Moreover Canvas LMS is wider than online class, for instance in LMS students can take lessons in online classroom and also in virtual classroom they can submit their assignments, do quiz, students can communicate with teacher and other learners and so on. In other words I can say that LMS is a learning organization to improve students' learning ability. Therefore by looking at those I can conclude that using Canvas LMS effective in the speaking classroom

\section{REFERENCES}

Adnan,M.A.M \& Hassan,S.S.S.,(2015). Promoting Interactions in Learning Arabic Language Via Learning Management System: A Theoretical Framework. GESJ: Education Science and Psychology.

Al- Tamimi,N.O.M., \& Attamimi, R.A.,(2014). Effectiveness of Cooperative Learning in Enhancing Speaking Skills and Attitudes towards Learning English. International Journal of Linguistics

Bude, et.al. (2005). The Importance of Interaction in Web-Based Education: A Program-level Case Study of Online MBA Courses. Journal of Interactive Online Learning, 4(1).

Canvas, LMS.Com. (2016). Unmute Learning with Arc. Retrieved fror https://www.canvaslms.com/.

Fallegi, P.I. (2010). Survey Methods and Practices. Canada : The National

Finances online.com. (2016). Canvas LMS review. Retrieved from https://reviews.financesonline.com/p/canvas-lms/.

Fleck, J. (2012). Blended learning and learning communities: opportunities and challenges. Journal of Management Development, 31(4), 398-411.

Guzera, B., \& Caner,H.(2014). The past, present and future of blended learning: an in depth analysis of literature. Procedia - Social and Behavioral Sciences.116, 4596 - 4603. Library of Canada.

Littilefiled, J. (2016).Canvas instructure review online learning platform with web 2.0 features. Retrieved from http://distancelearn.about.com/od/onlinecourses/gr/Canvas-InstructureReview.htm.

Manning,C., et.al (2011). Tech Tools for Teachers, By Teachers: Bridging Teachers and Students. Wisconsin English Journal

Mondal, P. (2016). Essay on Technology and Development. Article of Your Article Library. Retrieved from http://www.yourarticlelibrary.com/essay/essay-on-technology-and-development/30718/

Moore, M. G. (1989). Three types of interaction. The American Journal of Distance Education, 3(2), 1-6.

Norman, S.,(2016). Traditional Education and Advantages of Online Learning. Retrieved from https://elearningindustry.com/5-advantages-of-online-learning-education-withoutleaving-home.

Omer, M. et.al (2015). E-learning Opens Door to the Global Community: Novice Users' Experiences of E-learning in a Somali University. MERLOT Journal of Online Learning and 
Teaching, 11(2).

Reeves, K. (2015). Review: Instructure Canvas - 4 Years of Experience. Retrieved from https://www.trustradius.com/reviews/canvas-2015-09-18-12-40-00

Sidabalok, D. M. and Dharmawan Y.Y. (2017) The Role of Blended Learning in Activating Students' Speaking Ability. Proceedings of $4^{\text {th }}$ International Language and Language Teaching Conference, Yogyakarta.

Sidabalok., D.M. and Fitriana, S. (2018). The Analysis of Students' Critical Thinking in Online Discussion Forum by Uisng Schoology in Speaking B Class of First Semester Students of FKIP UBL. Linguistika: Jurnal Pendidikan Bahasa Inggris. Bandar Lampung: Program Studi Pendidikan Bahasa Inggris Fakultas Keguruaan dan Ilmu Pendidikan Univeritas Bandar Lampung

Sleeter, N. (2014). Meaningful Interaction in Online Courses. Retrieved from https://www.insidehighered.com/blogs/higher-ed-beta/meaningful-interaction-onlinecourses.

Somdee, M., \& Suppasetseree,S. (2012). Developing English Speaking Skills of Thai Undergraduate Students by Digital Storytelling through Websites.

Wheeler, S. (2012).Interaction of the fourth kind. Retrieved from http://www.stevewheeler.co.uk/2012/04/interactions-of-fourth-kind.html.

Woo, Y., \& Reeves,T,C.(2007). Meaningful interaction in web-based learning: A social constructivist interpretation. Journal of Internet and Higher Education

Woo,Y., \& Reeves,T,C. (2008), Interaction in asynchronous web based learning environments: strategies supported by educational research. Journal of Asynchronous Learning Networks

York, C.S., \& Richardson, J.C.(2012). Interpersonal Interaction In Online Learning: Experienced Online Instructors' Perceptions of Influencing Factors. Journal of Asynchronous Learning Networks,16(4).

Zimmerman, T. D. (2012). Exploring Learner to Content Interaction as a Success Factor in Online Courses. The International Review Of research In Open and Distributed Learning, 13(4). Retrieved from http://www.irrodl.org/index.php/irrodl/article/view/1302/2294 